\title{
ANALISIS PENERAPAN SKEMA FULLY FUNDED PADA SISTEM PENSIUN PEGAWAI NEGERI SIPIL DI INDONESIA
}

\author{
M. Zikri Eka Pratama \\ KPPN Palembang \\ Alamat Korespondensi: pratama.zikri@gmail.com
}

INFORMASI ARTIKEL

Diterima Pertama:

13 Juni 2016

Dinyatakan Diterima:

15 Agustus 2016

Kata Kunci:

Pension Fund Management, Social Security and Public Pension System, Pay As You Go Scheme, Fully Funded Pension Scheme, Fiscal Policy, State Budget.

Klasifikasi JEL:

H5, H6, G28, I38.

\section{ABSTRAK}

The implementation of fully funded pension scheme for civil servant retirement in Indonesia is one of the government solutions to reduce the burden of pension expenditure on the state budget. However, to implement such a scheme, the government deemed it necessary to prepare an appropriate governance model in order to achieve the goal of fully funded scheme. The government needs to pay attention to several issues related to the implementation of a fully funded scheme, namely the issue of pension fund management, contributions, investment, regulations and risks. By distributing questionnaires and interviews to key stakeholders, the extent of government readiness to implement a fully funded pension scheme could be evaluated, based on which it was found that the government does not have readiness to adopt the fully funded pension scheme and several tasks remain to be accomplished.

Penerapan skema fully funded pada sistem pensiun Pegawai Negeri Sipil di Indonesia merupakan salah satu alternatif yang akan diambil oleh pemerintah guna mengurangi beban belanja pensiun Pegawai Negeri Sipil pada Anggaran Pendapatan dan Belanja Negara (APBN). Namun untuk menerapkan skema tersebut, pemerintah dipandang perlu untuk menyiapkan suatu tata kelola agar tujuan dari penerapan skema fully funded ini dapat tercapai. Pemerintah perlu memperhatikan beberapa hal terkait rencana penerapan skema fully funded, yaitu masalah pengelola dana pensiun, iuran/ kontribusi peserta, investasi dana pensiun, peraturan, dan risiko. Dengan melakukan penyebaran kuesioner dan wawancara kepada narasumber, dalam penelitian ini dievaluasi sejauh mana kesiapan Indonesia dalam menerapkan skema fully funded pada sistem pensiun pegawai negeri: yang mana pemerintah tidak memiliki kesiapan untuk mengadopsi skema ini dan terdapat hal-hal yang harus dilakukan terkait dengan implementasi tersebut. 


\section{PENDAHULUAN}

\subsection{Latar Belakang}

Salah satu pos belanja yang sering dianggap membebani APBN adalah pos belanja pegawai. Pos belanja ini diberikan kepada para Pegawai Negeri Sipil (PNS) sehubungan dengan tugasnya memberikan layanan publik. Seiring dengan meningkatnya kebutuhan ekonomi, inflasi, dan perhatian pemerintah terhadap kesejahteraan PNS, maka membuat pos belanja pegawai ini semakin meningkat dari tahun ke tahun.

Jika membandingkan komposisi belanja pegawai dalam LKPP audited pada tahun anggaran (TA) 2007-2014, belanja pensiun memiliki proporsi yang cukup signifikan dari total belanja pegawai secara keseluruhan. Belanja pensiun ini dianggap salah satu belanja yang tidak produktif namun jumlahnya cukup besar sehingga membebani APBN. Berdasarkan LKPP TA 20072014, proporsi jumlah pembayaran pensiun dan uang tunggu terhadap total realisasi belanja pegawai rata-rata berkisar pada angka 31\% hingga $37 \%$. Realisasi belanja pensiun dari tahun ke tahun mengalami peningkatan hingga mencapai total Rp450,33 triliun dalam delapan tahun terakhir. Apabila tidak terjadi perubahan pelaksanaan sistem pensiun, maka hal tersebut dikhawatirkan akan semakin membebani APBN. ${ }^{1}$

Dengan alasan sebagaimana disebutkan di muka, maka perlu ada solusi untuk mengurangi beban APBN atas pembayaran pensiun PNS, yang diharapkan dapat memberikan ruang fiskal tambahan bagi pemerintah. Salah satu solusi yang diusulkan untuk keperluan tersebut adalah mengubah skema pendanaan pensiun dari sistem pay as you go (manfaat pasti), yaitu: sistem yang diterapkan saat ini, menjadi sistem fully funded (iuran pasti). Dengan perubahan skema pembayaran tersebut, diharapkan belanja pensiun tidak lagi membebani APBN.

Berdasarkan latar belakang masalah tersebut, penulis melakukan penelitian terhadap kesiapan pelaksanaan dan piranti yang perlu disiapkan dalam penerapan skema fully funded pada sistem pensiun PNS di Indonesia dalam rangka mengurangi beban belanja pensiun pada APBN Ruang lingkup penelitian ini adalah studi/ analisis penerapan skema fully funded pada sistem pensiun PNS di Indonesia, dengan melihat kesiapan pemerintah dam hal-hal yang perlu diperhatikan dalam menerapkan perubahan skema pensiun ini.

\footnotetext{
1 Menurut Direktur Perencanaan dan Pengembangan Teknologi Informasi PT. TASPEN (Persero), Faisal Rachman (www.bisnis.keuangankompas.com): belanja pensiun akan mencapai puncaknya pada tahun 2043 jumlah yang harus dibayarkan pada saat itu sekitar Rp300 triliun.
}

\section{KERANGKA TEORI}

\subsection{Pengertian Pensiun}

Pensiun merupakan suatu manfaat berupa tunjangan hari tua yang diperoleh para pegawai yang telah memenuhi syarat sebagai penerima pensiun. Dalam Undang-Undang No. 11 Tahun 1969 tentang Pensiun Pegawai dan Pensiun Janda/ Duda Pegawai, pada Pasal 1 disebutkan bahwa: "Pensiun pegawai dan pensiun janda/ duda menurut undang-undang ini diberikan sebagai jaminan hari tua dan sebagai penghargaan atas jasa-jasa pegawai negeri selama bertahun-tahun bekerja dalam Dinas Pemerintah." Berdasarkan Peraturan Pemerintah No. 25 Tahun 1981 tentang Asuransi Sosial Pegawai Negeri, pada Pasal 1, disebutkan: "Pensiun adalah penghasilan yang diterima oleh penerima pensiun setiap bulan berdasarkan peraturan perundang-undangan yang berlaku".

\subsection{Program Pensiun}

Menurut Undang-Undang No. 11 Tahun 1992 tentang Dana Pensiun, program pensiun merupakan setiap program yang mengupayakan manfaat bagi peserta. Jenis program pensiun pada dasarnya memiliki 2 (dua) alternatif yang bisa dikembangkan dengan berbagai model, yaitu: Program Pensiun Iuran Pasti dan Program Pensiun Manfaat Pasti.

Berdasarkan Undang-Undang No. 11 Tahun 1992 tentang Dana Pensiun, pada Pasal 1, disebutkan bahwa: Program Pensiun Manfaat Pasti adalah program pensiun yang manfaatnya ditetapkan dalam peraturan Dana Pensiun atau program pensiun lain yang bukan merupakan Program Pensiun Iuran Pasti.

Berdasarkan Undang-Undang No. 11 Tahun 1992 tentang Dana Pensiun, pada Pasal 1, disebutkan bahwa: Program Pensiun Iuran Pasti adalah program pensiun yang iurannya ditetapkan dalam peraturan Dana Pensiun dan seluruh iuran serta hasil pengembangannya dibukukan pada rekening masing-masing peserta sebagai manfaat pensiun.

\subsection{Dana Pensiun}

Menurut Pasal 1, angka 1, Undang-Undang No. 11 Tahun 1992 tentang Dana Pensiun dijelaskan pengertian Dana Pensiun adalah badan hukum yang mengelola dan menjalankan program yang menjadikan manfaat pensiun. Terdapat dua jenis dana pensiun berdasarkan Undang-Undang No. 11 Tahun 1992 tentang Dana Pensiun, yaitu Dana Pensiun Pemberi Kerja dan Dana Pensiun Lembaga Keuangan.

Dana Pensiun Pemberi Kerja adalah Dana Pensiun yang dibentuk oleh orang atau badan yang mempekerjakan kayawan selaku pendiri, untuk 
menyelenggarakan Program Pensiun Manfaat Pasti atau Program Pensiun Iuran Pasti, bagi kepentingan sebagian atau seluruh karyawannya sebagai peserta, dan yang menimbulkan kewajiban terhadap pemberi kerja. Dana Pensiun Lembaga Keuangan adalah Dana Pensiun yang dibentuk oleh bank atau perusahaan asuransi jiwa untuk menyelenggarakan Program Pensiun Iuran Pasti bagi perorangan baik karyawan maupun pekerja mandiri yang terpisah dari Dana Pensiun pemberi kerja bagi karyawan bank atau perusahaan asuransi jiwa yang bersangkutan.

\subsection{Pendanaan Pensiun}

Secara garis besar, terdapat dua jenis pendanaan dalam program pensiun, yaitu: 1). Fully funded dan 2). Unfunded atau pay as you go. Menurut Ponds-Severinson dan Yermo, pengertian skema fully funded dalam pembayaran pensiun adalah: "Funded Arrangement are those where an independent legal entity is established to hold pension plan member. Typically, assets would be held in a (legally separate) pension fund...".2 Selain itu, menurut Hyman "A fully funded pension system is one in which benefits are paid out of a fund built up from contributions by, or on behalf of, members in retirement system". ${ }^{3}$

Menurut Ponds-Severinson dan Yermo, unfunded atau pay-as-you-go adalah: "Arrangements are financed directly out of government's coffer, though there may reserve set up which are the legal property of the employer (government)". 4 Kemudian, menurut Heyman " $A$ pay as you go pension system is one that finance pensions for retired workers in a given year entirely by contributions or taxes paid by currently employed workers." 5

\subsection{Peraturan Tentang Pensiun di Indonesia}

Peraturan pertama yang terkait dengan pensiun PNS di Indonesia adalah Undang-Undang No. 11 Tahun 1969 tentang Pensiun Pegawai dan Pensiun Janda/ Duda Pegawai. Undang-Undang ini menggantikan Undang-Undang No. 20 Tahun 1952 tentang Pensiun Pegawai Negeri Sipil. Dalam Undang-Undang No. 11 Tahun 1969 yang terdiri

2 E. Ponds, C. Severinson and J. Yermo, "Funding in Public Sector Pension Plans: International Evidence", OECD Working Papers on Finance, Insurance and Private Pensions, 2011, No. 8, OECD Publishing, hlm. 7.

3 David N Hayman, Public Finance a Contemporary Aplication of Theory to Policy, (Mason: South-Western Cengage Learning, 2011), hlm. 314.

4 E. Ponds, et al., Op.Cit., hlm. 7.

5 David N Hayman, Op.Cit., hlm. 315 dari 35 pasal ini mengatur mengenai sifat dan pembiayaan pensiun, dasar pensiun, hak atas pensiun, besaran pensiun pegawai, besaran pensiun janda/ duda PNS, dan ketentuan mengenai pensiun janda/ duda. Besaran pensiun pegawai perbulan berdasarkan peraturan ini adalah 2,5\% dari dasar pensiun untuk tiap-tiap tahun masa kerja, dengan ketentuan bahwa pensiun pegawai sebulan sebanyak-banyaknya $75 \%$ dari dasar pensiun. Kemudian, disebutkan bahwa jumlah pensiun yang diterima pegawai dalam satu bulan tidak boleh kurang atau lebih kecil dari gaji pokok terendah menurut Peraturan Pemerintah tentang gaji dan pangkat yang berlaku bagi pegawai negeri yang bersangkutan.

Peraturan berikutnya yang terkait dengan pensiun PNS di Indonesia adalah Peraturan Pemerintah No. 25 Tahun 1981 Tentang Asuransi Sosial Pegawai Negeri Sipil. Dalam peraturan pemerintah ini mengatur mengenai kepesertaan, hak dan kewajiban peserta (PNS), sumbangan pemerintah, badan penyelenggara asuransi sosial PNS, dan jaminan negara. Dalam peraturan ini, disebutkan bahwa setiap peserta diwajibkan untuk membayar iuran setiap bulan sebesar $8 \%$ dari penghasilan sebulan tanpa tunjangan pangan dengan rincian sebagai berikut: $4,75 \%$ diperuntukkan sebagai iuran pensiun, dan 3,25\% diperuntukkan sebagai tabungan hari tua.

Peraturan terkait pensiun PNS lainnya adalah Peraturan Pemerintah No. 15 Tahun 1963 tentang Pendirian Perusahaan Negara Dana Tabungan dan Asuransi Pegawai Negeri. Dalam Peraturan ini mengatur mengenai hal-hal terkait Perusahaan Negara Dana Tabungan dan Asuransi Pegawai Negeri, termasuk kebijakan mengenai investasi modal.

Undang-Undang No. 11 Tahun 1992 Tentang Dana Pensiun, secara umum mengatur mengenai penyelenggaraan Dana Pensiun. Dalam UndangUndang ini disebutkan bahwa Dana Pensiun merupakan sarana penghimpun dana guna meningkatkan kesejahteraan peserta, serta meningkatkan peran masyarakat dalam melestarikan pembangunan nasional yang meningkat dan berkelanjutan. Dan juga, Dana Pensiun dapat pula meningkatkan motivasi dan ketenangan kerja untuk peningkatan produktivitas.

Peraturan terkait pensiun berikutnya adalah Undang-Undang No. 5 Tahun 2014 Tentang Aparatur Sipil Negara. Dalam Undang-Undang ini diatur mengenai penambahan batas usia pensiun yaitu 58 tahun untuk Pejabat Administrasi, 60 tahun Pejabat Pimpinan Tinggi dan sesuai dengan peraturan perundang-undangan bagi pejabat fungsional. Kemudian pada Undang-Undang ini 
juga disebutkan bahwa pendanaan pensiun PNS berasal dari iuran pegawai dan juga pemerintah.

\section{METODOLOGI PENELITIAN}

Bagian ini menguraikan metode/ teknik/ cara yang digunakan untuk memperoleh/ menjelaskan suatu kebenaran yang bersifat ilmiah dengan menggunakan penelusuran dengan basis sistematika dan tata cara tertentu sesuai dengan obyek penelitian yang dilakukan secara ilmiah, yang secara general dapat diterima/ digunakan dalam suatu disiplin keilmuan. Kegiatan yang dilaksanakan dalam rangka membangun metodologi penelitian diantaranya adalah dengan melakukan seleksi dan pengumpulan data, pengukuran dan definisi operasional variable, dan metode analisis data.

\subsection{Objek Penelitian}

Objek dalam penelitian ini adalah studi sistem pensiun PNS di Indonesia dan studi kemungkinan penerapan skema fully funded pada sistem pensiun PNS yang menggantikan skema pay as you go sebagai solusi dalam mengurangi beban APBN.

\subsection{Jenis dan Sumber Data}

Jenis data yang digunakan dalam penelitian ini adalah data primer dan sekunder. Data primer merupakan data yang diperoleh langsung melalui wawancara dan kuesioner, sedangkan data sekunder merupakan data yang diperoleh dari dokumen-dokumen resmi dari instansi, buku-buku yang relevan, jurnal terkait sistem pensiun, serta publikasi lainnya.

\subsection{Metode Pengolahan Data}

Penelitian ini menggunakan metode deskriptif kualitatif yang dirancang untuk mengumpulkan informasi tentang keadaan-keadaan yang sesungguhnya terjadi. Menurut Sugiyono penelitian kualitatif didefinisikan sebagai suatu metode penelitian berdasarkan filsafat postpositivisme. ${ }^{6}$

\section{HASIL PENELITIAN}

Untuk mendapatkan jawaban atas rumusan masalah penelitian, penulis melakukan pengumpulan data penelitian dengan menggunakan kuesioner untuk mendapatkan tanggapan dari para responden mengenai hal-hal yang perlu diperhatikan sehubungan dengan penerapan skema fully funded pada sistem pensiun PNS di Indonesia. Setelah hasil kuesioner didapatkan, penulis melakukan wawancara kepada narasumber yang memahami sistem pensiun PNS di Indonesia. Pertanyaan-pertanyaan yang

6 Sugiyono, Metode Penelitian Kuantitatif Kualitatif dan R\&D, (Jakarta: Alfabeta, 2012). diajukan kepada narasumber merupakan pertanyaan yang terkait dengan rumusan masalah dalam penelitian ini.

Responden kuesioner yang dipilih adalah pejabat dan pegawai di instansi yang terlibat dalam perumusan kebijakan serta pelaksanaan sistem pensiun pegawai negeri di Indonesia. Instansi yang menjadi responden adalah Kementerian Pemberdayaan Aparatur Negara dan Reformasi Birokrasi (PAN-RB), Direktorat Jenderal Anggaran (DJA) Kementerian Keuangan, Direktorat Jenderal Perbendaharaan (DJPB) Kementerian Keuangan, dan PT. TASPEN. Wawancara dilakukan kepada narasumber yang terkait langsung dalam perumusan kebijakan pensiun yaitu Kepala Bidang Penyiapan Perumusan Pensiun SDM Aparatur pada Kementerian PAN-RB, Kepala Seksi Harmonisasi Peraturan Jaminan Pensiun dan Hari Tua DJA Kementerian Keuangan, dan Kepala Seksi Program Pensiun DJPB Kementerian Keuangan. Narasumber merupakan pejabat yang menangani dan terlibat langsung dalam perumusan sistem jaminan pensiun pegawai negeri di Indonesia.

Secara garis besar, pertanyaan-pertanyaan yang diajukan kepada responden kuesioner dan narasumber dapat dikelompokkan menjadi lima kelompok besar yaitu: pengelola dana pensiun, iuran/ kontribusi, investasi dana pensiun, peraturan, dan risiko.

\subsection{Pengelola Dana Pensiun}

Lembaga pengelola dana pensiun memegang peranan penting dalam pelaksanaan sistem pensiun. Pada saat ini pengelola dana pensiun pegawai negeri masih dilaksanakan oleh PT. TASPEN. Berdasarkan data yang diperoleh, PT. TASPEN dipandang perlu meningkatkan tugas pokok dan fungsinya secara lebih optimal. PT. TASPEN dalam operasionalnya masih terdapat pembatasan-pembatasan dalam menginvestasikan dana pensiun, dimana investasi hanya diperbolehkan pada instrumen pembiayaan yang dikeluarkan oleh pemerintah. Selain itu, dana yang dikumpulkan dari peserta juga sangat kecil sehingga menyebabkan PT. TASPEN mengalami unfunded dan tidak dapat membiayai pembayaran pensiun secara utuh kepada pegawai negeri.

Hasil pengolahan data dari kuesioner yang dikumpulkan mengenai Pengelola Dana Pensiun dapat dilihat pada Tabel 4.1. Berdasarkan hasil distribusi frekuensi subbagian pengelola dana pensiun, dapat diketahui bahwa sebanyak $24 \%$ responden sangat setuju dan 59\% responden setuju adanya perbaikan-perbaikan pada pengelola dana pensiun sehinga dapat menerapkan skema fully funded, sedangkan sebanyak 7\% responden bersikap netral terhadap kemungkinan perubahan tersebut, dan sebanyak $2 \%$ menyatakan tidak 
setuju dan 8\% menyatakan sangat tidak setuju apabila skema fully funded diterapkan.

Jika dilihat dari jumlah pembobotan nilai kuesioner pada bagian ini, secara umum, jumlah nilai bagian ini sebesar 351 dengan nilai rata-rata sebesar 3,9. Jumlah ini berada pada rentang pendapat netral (N) dan setuju (S). Pengolahan jawaban responden terhadap pernyataan P1 kuesioner menunjukkan bahwa sebanyak 11 responden $(36,7 \%)$ berpendapat bahwa mereka sangat setuju dan sebanyak 17 responden $(56,7 \%)$ berpendapat bahwa mereka setuju apabila skema fully funded diterapkan pada sistem pensiun PNS di Indonesia, maka lembaga pengelola dana pensiun harus merupakan entitas yang independen, sedangkan terdapat 2 responden $(6,7 \%)$ yang bersikap netral bahwa lembaga pengelola dana pensiun harus merupakan entitas yang independen apabila skema fully funded diterapkan pada sistem pensiun PNS di Indonesia.

Berdasarkan hasil perhitungan nilai rata-rata pembobotan kuesioner, pernyataan P1 bernilai sebesar 129 poin, dengan nilai rata-rata sebesar 4,30 . Poin 4,30 ini berada pada rentang pendapat setuju (S) dan sangat setuju (SS). Hal ini menunjukkan bahwa responden setuju dengan pernyataan apabila pemerintah akan menerapkan skema fully funded pada sistem pensiun PNS di Indonesia, maka lembaga pengelola dana pensiun harus merupakan entitas yang independen.

Pengolahan jawaban responden terhadap pernyataan P2 kuesioner menunjukkan bahwa sebanyak 6 responden (20\%) berpendapat bahwa mereka sangat setuju dan sebanyak 22 responden $(73.3 \%)$ berpendapat bahwa mereka setuju apabila skema fully funded diterapkan pada sistem pensiun PNS di Indonesia, lembaga pengelola dana pensiun harus memiliki kewenangan dalam menentukan kebijakan, sedangkan terdapat 2 responden $(6,7 \%)$ yang bersikap netral bahwa lembaga pengelola dana pensiun harus memiliki kewenangan dalam menentukan kebijakan apabila skema fully funded diterapkan pada sistem pensiun PNS di Indonesia.

Berdasarkan hasil perhitungan nilai rata-rata pembobotan kuesioner, pernyataan P2 bernilai sebesar 124 poin, dengan nilai rata-rata sebesar 4,13 . Poin 4,13 ini berada pada rentang pendapat setuju (S) dan sangat setuju (SS). Hal ini menunjukkan bahwa responden setuju dengan pernyataan apabila pemerintah menerapkan skema fully funded pada sistem pensiun PNS di Indonesia, maka lembaga pengelola dana pensiun harus memiliki kewenangan dalam menentukan kebijakan.

Pengolahan jawaban responden terhadap pernyataan P3 kuesioner menunjukkan bahwa sebanyak 5 responden (16,7\%) berpendapat bahwa mereka sangat setuju dan sebanyak 14 responden $(46,7 \%)$ berpendapat bahwa mereka setuju apabila skema fully funded diterapkan pada sistem pensiun PNS di Indonesia, maka lembaga pengelola dana pensiun harus memiliki kewenangan dalam menggunakan dan memanfaatkan dana pensiun dalam rangka operasional. Namun terdapat 7 responden $(23,3 \%)$ sangat tidak setuju dan sebanyak 2 responden $(6,7 \%)$ tidak setuju dengan pernyataan ini, sedangkan terdapat 2 responden $(6,7 \%)$ yang bersikap netral bahwa lembaga pengelola dana pensiun harus memiliki kewenangan dalam menggunakan dan memanfaatkan dana pensiun dalam rangka operasional sehubungan dengan penerapan skema fully funded pada sistem pensiun PNS di Indonesia.

Berdasarkan hasil perhitungan nilai rata-rata pembobotan kuesioner, pernyataan P3 bernilai sebesar 98 poin, dengan nilai rata-rata sebesar 3,27 . Poin 3,27 ini berada pada rentang pendapat netral (N) dan setuju (S). Hal ini menunjukkan bahwa responden cenderung netral dengan pernyataan apabila pemerintah akan menerapkan skema fully funded pada sistem pensiun PNS di Indonesia, maka lembaga pengelola dana pensiun harus memiliki kewenangan dalam menggunakan dan memanfaatkan dana pensiun dalam rangka operasional.

Berdasarkan wawancara yang dilakukan dengan narasumber, ketika pemerintah akan menerapkan skema fully funded, maka diusulkan bahwa yang melaksanakan fungsi pengelolaan dana pensiun adalah Kementerian Keuangan c.q. Direktorat Jenderal Perbendaharaan dengan membentuk unit khusus yang menangani pengelolaan pensiun. Hal ini dilakukan dengan tujuan untuk menekan biaya operasional dari pengelolaan dana pensiun pegawai. Pembentukan badan pengelola dana pensiun dibawah kewenangan pemerintah secara langsung merupakan hal yang wajar dan umum diterapkan di berbagai negara, salah satunya adalah Malaysia. Lembaga dana pensiun di Malaysia berada di bawah Kementerian dan berada dalam kekuasaan pemerintah. Namun pada sifat Satuan Kerja saat ini, tidak dimungkinkan suatu Satuan Kerja mengelola dana yang bukan berasal dari APBN, PNBP, atau Pendapatan BLU.

Dari sisi ini, dapat dikatakan bahwa pemerintah dapat menerapkan skema fully funded karena telah memiliki lembaga pengelola dana pensiun, dan juga sedang melakukan upaya perbaikan dari sisi pengelola dengan mengusulkan penggantian instansi pengelola dana pensiun. Akan tetapi, dari sisi kesiapan, dapat dikatakan pemerintah belum siap untuk melaksanakan perubahan ini dikarenakan masih belum adanya kesepakatan dan keputusan final yang tertuang dalam Peraturan Pemerintah. 


\subsection{Iuran/ Kontribusi}

Berdasarkan hasil dari kuesioner yang diperoleh dan diolah, Kementerian PAN-RB, Direktorat Jenderal Perbendaharaan, Direktorat Jenderal Anggaran, dan PT TASPEN selaku pihakpihak yang terlibat dalam kebijakan pensiun pegawai negeri di Indonesia dapat dikatakan setuju apabila pemerintah akan menerapkan skema fully funded pada sistem pensiun pegawai negeri. Oleh karena itu, pemerintah dan peserta, dalam hal ini PNS, harus bersama-sama melakukan pengiuran kepada dana pensiun. Saat pensiun dibayar melalui APBN, pemerintah menerapkan skema pay as you go yang mana hanya pegawai negeri saja yang melakukan pengiuran kepada dana pensiun, sedangkan pemerintah tidak melakukan pengiuran. Hal ini menyebabkan dana yang terkumpul pada PT. TASPEN untuk dikembangkan tidak cukup besar dan berdampak pada kemampuan PT. TASPEN untuk membayar pensiun PNS. Oleh karena itu, apabila skema fully funded diterapkan, maka pemerintah harus melakukan pengiuran kepada dana pensiun sehingga dana yang terkumpul dapat maksimal dan dapat dikembangkan untuk mendapatkan hasil yang maksimal.

Hasil pengolahan data dari kuesioner yang dikumpulkan mengenai iuran/ kontribusi dapat dilihat pada Tabel 4.2. Berdasarkan hasil distribusi frekuensi subbagian iuran/ kontribusi peserta, dapat diketahui bahwa sebanyak 37\% responden sangat setuju dan $42 \%$ responden setuju bahwa iuran/ kontribusi peserta pensiun harus diubah sehingga dapat menerapkan skema fully funded, sedangkan sebanyak $21 \%$ responden bersikap netral terhadap kemungkinan perubahan pada iuran/ kontribusi peserta pesiun apabila skema fully funded diterapkan.

Jika dilihat dari jumlah pembobotan nilai kuesioner pada bagian ini, secara umum, jumlah nilai bagian ini sebesar 374 dengan nilai rata-rata sebesar 4,15. Jumlah ini berada pada rentang pendapat setuju (S) dan sangat setuju (SS).

Pengolahan jawaban responden terhadap pernyataan P4 kuesioner menunjukkan bahwa sebanyak 9 responden $(30 \%)$ berpendapat bahwa mereka sangat setuju dan sebanyak 15 responden (50\%) berpendapat bahwa mereka setuju apabila skema fully funded diterapkan pada sistem pensiun PNS di Indonesia, maka Pemerintah dan PNS harus bersama-sama melakukan pembayaran iuran dengan mekanisme sharing method, sedangkan terdapat 6 responden $(20 \%)$ yang bersikap netral bahwa Pemerintah dan PNS harus bersama-sama melakukan pembayaran iuran dengan mekanisme sharing method apabila skema fully funded diterapkan pada sistem pensiun PNS di Indonesia.
Berdasarkan hasil perhitungan nilai rata-rata pembobotan kuesioner, pernyataan P4 bernilai sebesar 123 poin, dengan nilai rata-rata sebesar 4,10. Poin 4,10 ini berada pada rentang pendapat setuju (S) dan sangat setuju (SS). Hal ini menunjukkan bahwa responden setuju dengan pernyataan apabila pemerintah akan menerapkan skema fully funded pada sistem pensiun PNS di Indonesia, maka Pemerintah dan PNS harus bersama-sama melakukan pembayaran iuran dengan mekanisme sharing method.

Pengolahan jawaban responden terhadap pernyataan P5 kuesioner menunjukkan bahwa sebanyak 11 responden $(36,7 \%)$ berpendapat bahwa mereka sangat setuju dan sebanyak 16 responden $(53,3 \%)$ berpendapat bahwa mereka setuju apabila skema fully funded diterapkan pada sistem pensiun PNS di Indonesia, jumlah premi iuran untuk pensiun saat ini perlu ditingkatkan, sedangkan terdapat 3 responden (10\%) bersikap netral mengenai jumlah premi iuran untuk pensiun saat ini perlu ditingkatkan apabila skema fully funded diterapkan pada sistem pensiun PNS di Indonesia.

Berdasarkan hasil perhitungan nilai rata-rata pembobotan kuesioner, pernyataan P5 bernilai sebesar 128 poin, dengan nilai rata-rata sebesar 4,27 . Poin 4,27 ini berada pada rentang pendapat setuju (S) dan sangat setuju (SS). Hal ini menunjukkan bahwa responden setuju dengan pernyataan apabila pemerintah akan menerapkan skema fully funded pada sistem pensiun PNS di Indonesia, maka jumlah premi iuran untuk pensiun saat ini perlu ditingkatkan.

Pengolahan jawaban responden terhadap pernyataan P6 kuesioner menunjukkan bahwa sebanyak 13 responden $(43,3 \%)$ berpendapat bahwa mereka sangat setuju dan sebanyak 7 responden $(23,3 \%)$ berpendapat bahwa mereka setuju apabila skema fully funded diterapkan pada sistem pensiun PNS di Indonesia, maka setiap PNS perlu dibuatkan rekening dana pensiun masingmasing oleh pengelola dana pensiun, sedangkan terdapat 10 responden $(33,3 \%)$ bersikap netral mengenai setiap PNS perlu dibuatkan rekening dana pensiun masing-masing oleh pengelola dana pensiun apabila skema fully funded diterapkan pada sistem pensiun PNS di Indonesia.

Berdasarkan hasil perhitungan nilai rata-rata pembobotan kuesioner, pernyataan P6 bernilai sebesar 123 poin, dengan nilai rata-rata sebesar 4,10. Poin 4,10 ini berada pada rentang pendapat setuju (S) dan sangat setuju (SS). Hal ini menunjukkan bahwa responden setuju dengan pernyataan apabila pemerintah akan menerapkan skema fully funded pada sistem pensiun PNS di Indonesia, maka setiap PNS perlu dibuatkan 
rekening dana pensiun masing-masing oleh pengelola dana pensiun.

Berdasarkan hasil dari kuesioner yang diperoleh dan diolah, Kementerian PAN-RB, Direktorat Jenderal Perbendaharaan, Direktorat Jenderal Anggaran, dan PT TASPEN selaku pihakpihak yang terlibat dalam kebijakan pensiun pegawai negeri di Indonesia dapat dikatakan setuju apabila pemerintah akan menerapkan skema fully funded pada sistem pensiun pegawai negeri, maka jumlah premi iuran untuk pensiun saat ini perlu ditingkatkan. Saat ini, jumlah potongan gaji yang digunakan sebagai iuran pensiun pegawai negeri sebesar 4,75\% dari gaji. Jumlah ini dinilai tidak cukup besar ketika skema fully funded akan diterapkan. Negara Chile ketika menerapkan skema fully funded menetapkan iuran/ kontribusi peserta kepada dana pensiun sebesar 10\% dari gaji. Sementara itu, Malaysia menetapkan iuran sebesar 20-25\% iuran peserta kepada dana pensiun. Ketika skema fully funded diterapkan, dan pada saat itu juga pensiun akan dibayarkan menggunakan dana berasal dari iuran/ kontribusi serta hasil pengembangannya, maka iuran sebesar $4,75 \%$ dikhawatirkan tidak akan maksimal memberikan jaminan pensiun kepada pegawai negeri. Tentunya besaran pensiun yang ideal harus melalui perhitungan aktuaria, namun keempat instansi sebagai narasumber responden setuju bahwa iuran/ kontribusi peserta harus ditingkatkan lagi.

Berdasarkan informasi yang diperoleh dari wawancara juga dapat dikatakan bahwa pemerintah, dalam hal ini Kementerian PAN-RB, telah mengusulkan iuran harus dinaikkan. Dalam rancangan peraturan pemerintah yang sedang disusun, diusulkan iuran yang dipungut dari peserta dan pemerintah adalah 11\%. Namun demikian, hal yang perlu menjadi perhatian pemerintah adalah sumber dana yang digunakan untuk membiayai iuran pemerintah. Sumber dana yang diusulkan adalah berasal dari PPh 21 gaji pegawai, namun sumber dana dari $P P h 21$ secara riil tidak ada, hanya berupa angka saja. Sehingga untuk menanggulangi hal tersebut, menurut narasumber dapat dilakukan dengan membuat $\mathrm{PPh}$ 21 dibayarkan secara riil seperti halnya $P P h 21$ pada tunjangan kinerja.

Ketika skema fully funded diterapkan, maka diperlukan adanya akun pribadi yang menunjukkan besarnya posisi saldo akun untuk masing-masing peserta. Sehingga hal ini memungkinkan peserta untuk mengetahui berapa besar iuran yang telah disetorkan dan hasil dari pengembangan. Skema fully funded memungkinkan akun pribadi peserta tersebut untuk dipindahkan ke lembaga pensiun lain ketika peserta tesebut berganti pekerjaan. Karena peserta memiliki rekening pribadi, maka dimungkinkan pula peserta dapat menentukan apakah akan mengambil pensiun mereka secara langsung atau secara annuitas. Berdasarkan kuesioner yang telah diterima dan diolah, keempat instansi sebagai narasumber responden setuju bahwa setiap peserta pensiun perlu untuk dibuatkan akun pribadi dana pensiun masing-masing.

\subsection{Investasi Dana Pensiun}

Investasi dana pensiun yang dilakukan oleh lembaga pensiun yang ditunjuk oleh pemerintah merupakan hal yang krusial dalam pelaksanaan jaminan pensiun. Investasi yang dilakukan oleh lembaga pensiun akan menghasilkan pengembalian yang dapat menambah saldo dana pensiun yang akan digunakan oleh lembaga pensiun membayar kewajiban kepada peserta pada saat memasuki usia pensiun. Namun, investasi yang dilakukan dapat pula mengalami risiko seperti kerugian ataupun hasil yang diraih tidak sesuai dengan keinginan (tidak optimal). Dengan demikian, diperlukan adanya portofolio surat berharga dalam pelaksanaan investasi dana yang terkumpul dari peserta sehingga risiko kerugian investasi dapat dikurangi.

Hasil pengolahan data dari kuesioner yang dikumpulkan mengenai Investasi Dana Pensiun dapat dilihat pada Tabel 4.3. Berdasarkan hasil distribusi frekuensi subbagian investasi dana pensiun, dapat diketahui bahwa sebanyak $24,4 \%$ responden sangat setuju dan 46,7\% responden setuju bahwa investasi dana pensiun harus ditingkatkan kinerjanya sehinga dapat menerapkan skema fully funded, sedangkan sebanyak 18,9\% responden bersikap netral terhadap kemungkinan perubahan pada investasi dana pensiun apabila skema fully funded diterapkan. Namun demikian, sebanyak 7,8\% responden sangat tidak setuju dan 2,2\% tidak setuju dengan kemungkinan perubahan pada investasi dana pensiun apabila skema fully funded diterapkan.

Jika dilihat dari jumlah pembobotan nilai kuesioner pada bagian ini, secara umum, jumlah nilai bagian ini sebesar 340 dengan nilai rata-rata sebesar 3,77. Jumlah ini berada pada rentang pendapat netral $(\mathrm{N})$ dan setuju $(\mathrm{S})$.

Pengolahan jawaban responden terhadap pernyataan P7 kuesioner menunjukkan bahwa sebanyak 8 responden $(26,7 \%)$ berpendapat bahwa mereka sangat setuju dan sebanyak 15 responden $(50 \%)$ berpendapat bahwa mereka setuju apabila skema fully funded diterapkan pada sistem pensiun PNS di Indonesia, maka untuk meminimalkan risiko, investasi dana pensiun dapat diinvestasikan dalam bentuk portofolio surat berharga. Terdapat 7 responden $(23,3 \%)$ yang bersikap netral bahwa untuk meminimalkan risiko, investasi dana pensiun dapat diinvestasikan dalam 
bentuk portofolio surat berharga sehubungan dengan penerapan skema fully funded pada sistem pensiun PNS di Indonesia.

Berdasarkan hasil perhitungan nilai rata-rata pembobotan kuesioner, pernyataan P7 bernilai sebesar 121 poin, dengan nilai rata-rata sebesar 4,03. Poin 4,03 ini berada pada rentang pendapat setuju (S) dan sangat setuju (SS). Hal ini menunjukkan bahwa responden setuju dengan pernyataan apabila pemerintah akan menerapkan skema fully funded pada sistem pensiun PNS di Indonesia, untuk meminimalkan risiko, investasi dana pensiun dapat diinvestasikan dalam bentuk portofolio surat berharga.

Pengolahan jawaban responden terhadap pernyataan P8 kuesioner menunjukkan bahwa sebanyak 10 responden (33,3\%) berpendapat bahwa mereka sangat setuju dan sebanyak 20 responden $(66,7 \%)$ berpendapat bahwa mereka setuju apabila skema fully funded diterapkan pada sistem pensiun PNS di Indonesia, maka investasi dana pensiun harus menghasilkan tingkat pengembalian yang optimal.

Berdasarkan hasil perhitungan nilai rata-rata pembobotan kuesioner, pernyataan P8 bernilai sebesar 130 poin, dengan nilai rata-rata sebesar 4,33. Poin 4,33 ini berada pada rentang pendapat setuju (S) dan sangat setuju (SS). Hal ini menunjukkan bahwa responden setuju dengan pernyataan apabila pemerintah akan menerapkan skema fully funded pada sistem pensiun PNS di Indonesia, maka investasi dana pensiun harus menghasilkan tingkat pengembalian yang optimal.

Pengolahan jawaban responden terhadap pernyataan P9 kuesioner menunjukkan bahwa sebanyak 4 responden $(13,3 \%)$ berpendapat bahwa mereka sangat setuju dan sebanyak 7 responden $(23,3 \%)$ berpendapat bahwa mereka setuju apabila skema fully funded diterapkan pada sistem pensiun PNS di Indonesia, maka dana pensiun diperkenankan untuk diinvestasikan pada sektor privat. Namun terdapat 7 responden $(23,3 \%)$ sangat tidak setuju dan sebanyak 2 responden $(6,7 \%)$ tidak setuju dengan pernyataan ini, sedangkan terdapat 10 responden $(33,3 \%)$ yang bersikap netral bahwa dana pensiun diperkenankan untuk diinvestasikan pada sektor privat sehubungan dengan penerapan skema fully funded pada sistem pensiun PNS di Indonesia.

Berdasarkan hasil perhitungan nilai rata-rata pembobotan kuesioner, pernyataan P9 bernilai sebesar 89 poin, dengan nilai rata-rata sebesar 2,97. Poin 2,97 ini berada pada rentang pendapat tidak setuju (TS) dan Netral (N). Hal ini menunjukkan bahwa responden cenderung netral dengan pernyataan apabila pemerintah akan menerapkan skema fully funded pada sistem pensiun PNS di Indonesia, maka dana pensiun diperkenankan untuk diinvestasikan pada sektor privat.

Berdasarkan kuesioner yang telah diterima dan diolah, keempat instansi sebagai narasumber responden setuju bahwa untuk meminimalkan risiko dalam investasi dana pensiun, maka dana yang terkumpul dari para peserta dapat diinvestasikan dalam portofolio surat berharga.

Namun, berdasarkan hasil wawancara kepada narasumber, investasi dana pensiun tidak dapat diinvestasikan pada sektor swasta, mengingat resiko yang sulit dikendalikan oleh pemerintah. Investasi dana pensiun harus dibatasi hanya pada instrumen pembiayaan pemerintah yang lebih aman, walaupun dengan resiko tingkat pengembalian tersebut tidak menghasilkan return yang paling optimal.

\subsection{Peraturan}

Ketika skema fully funded diterapkan dan menggantikan skema pay as you go, maka pemerintah tidak akan lagi membayar manfaat pensiun kepada para pegawai negeri yang pensiun karena semua manfaat pensiun akan dibayarkan oleh lembaga pensiun yang ditunjuk oleh pemerintah dengan menggunakan dana yang telah dikumpulkan dari peserta. Tetapi dalam investasi terjadi kemungkinan kerugian yang dialami oleh lembaga pensiun yang akan menyebabkan nilai saldo dana pensiun masing-masing peserta menurun. Ketika hal itu tejadi, terdapat kemungkinan jumlah manfaat pensiun yang diterima peserta justru lebih kecil dari manfaat yang diterima ketika skema pay as you go digunakan. Chile, ketika menerapkan skema fully funded pada sistem pensiunnya membuat kebijakan bahwa pemerintah menanggung jumlah minimal pensiun apabila terjadi hal-hal diluar kondisi yang diharapkan.

Hasil pengolahan data dari kuesioner yang dikumpulkan mengenai Peraturan dapat dilihat pada Tabel 4.4. Berdasarkan hasil distribusi frekuensi subbagian peraturan mengenai pensiun, dapat diketahui bahwa sebanyak $23,3 \%$ responden sangat setuju dan 57,5\% responden setuju bahwa peraturan mengenai pensiun PNS harus diubah agar dapat menerapkan skema fully funded. Terdapat 7,5\% responden sangat tidak setuju dan 8,3\% tidak setuju dengan adanya perubahan peraturan, sedangkan sebanyak 3,3\% responden bersikap netral terhadap kemungkinan perubahan peraturan mengenai pensiun PNS apabila skema fully funded diterapkan.

Jika dilihat dari jumlah pembobotan nilai kuesioner pada bagian ini, secara umum, jumlah nilai bagian ini sebesar 457 dengan nilai rata-rata sebesar 3,80. Jumlah ini berada pada rentang pendapat netral $(\mathrm{N})$ dan setuju $(\mathrm{S})$. 
Pengolahan jawaban responden terhadap pernyataan P10 kuesioner menunjukkan bahwa sebanyak 9 responden (30\%) berpendapat bahwa mereka sangat setuju dan sebanyak 20 responden $(66,7 \%)$ berpendapat bahwa mereka setuju apabila skema fully funded diterapkan pada sistem pensiun PNS di Indonesia, maka kejelasan skema pensiun yang digunakan diakomodasi dalam peraturan, sedangkan terdapat 1 responden (3,3\%) yang bersikap netral bahwa kejelasan skema pensiun yang digunakan harus diakomodasi dalam peraturan sehubungan dengan penerapan skema fully funded pada sistem pensiun PNS di Indonesia.

Berdasarkan hasil perhitungan nilai rata-rata pembobotan kuesioner, pernyataan P10 bernilai sebesar 128 poin, dengan nilai rata-rata sebesar 4,27. Poin 4,27 ini berada pada rentang pendapat setuju (S) dan sangat setuju (SS). Hal ini menunjukkan bahwa responden cenderung setuju dengan pernyataan apabila pemerintah akan menerapkan skema fully funded pada sistem pensiun pegawai negeri sipil di Indonesia, maka kejelasan skema pensiun yang digunakan diakomodasi dalam peraturan.

Pengolahan jawaban responden terhadap pernyataan P11 kuesioner menunjukkan bahwa sebanyak 13 responden (43,3\%) berpendapat bahwa mereka sangat setuju dan sebanyak 17 responden $(56,7 \%)$ berpendapat bahwa mereka setuju apabila skema fully funded diterapkan pada sistem pensiun PNS di Indonesia, maka terdapat pengaturan yang jelas atas kewajiban pemerintah untuk melakukan iuran kepada dana pensiun.

Berdasarkan hasil perhitungan nilai rata-rata pembobotan kuesioner, pernyataan P11 bernilai sebesar 133 poin, dengan nilai rata-rata sebesar 4,43 . Poin 4,43 ini berada pada rentang pendapat setuju (S) dan sangat setuju (SS). Hal ini menunjukkan bahwa responden cenderung setuju dengan pernyataan apabila pemerintah akan menerapkan skema fully funded pada sistem pensiun pegawai negeri sipil di Indonesia, maka harus terdapat pengaturan yang jelas atas kewajiban pemerintah untuk melakukan iuran kepada dana pensiun.

Pengolahan jawaban responden terhadap pernyataan P12 kuesioner menunjukkan bahwa sebanyak 3 responden (10\%) berpendapat bahwa mereka sangat setuju dan sebanyak 17 responden $(56,7 \%)$ berpendapat bahwa mereka setuju apabila skema fully funded diterapkan pada sistem pensiun PNS di Indonesia, maka ketentuan adanya penjaminan minimal pensiun apabila investasi dana pensiun mengalami kegagalan harus diakomodasi dalam peraturan. Namun terdapat 4 responden $(13,3 \%)$ sangat tidak setuju dan sebanyak 5 responden (16,7\%) tidak setuju dengan pernyataan ini, sedangkan terdapat 1 responden
$(3,3 \%)$ yang bersikap netral bahwa ketentuan adanya penjaminan minimal pensiun apabila investasi dana pensiun mengalami kegagalan harus diakomodasi dalam peraturan sehubungan dengan penerapan skema fully funded pada sistem pensiun PNS di Indonesia.

Berdasarkan hasil perhitungan nilai rata-rata pembobotan kuesioner, pernyataan P12 bernilai sebesar 100 poin, dengan nilai rata-rata sebesar 3,33 . Poin 3,33 ini berada pada rentang pendapat netral (N) dan setuju (S). Hal ini menunjukkan bahwa responden cenderung netral dengan pernyataan apabila pemerintah akan menerapkan skema fully funded pada sistem pensiun PNS di Indonesia, maka ketentuan adanya penjaminan minimal pensiun apabila investasi dana pensiun mengalami kegagalan harus diakomodasi dalam peraturan.

Pengolahan jawaban responden terhadap pernyataan P13 kuesioner menunjukkan bahwa sebanyak 3 responden (10\%) berpendapat bahwa mereka sangat setuju dan sebanyak 15 responden (50\%) berpendapat bahwa mereka setuju apabila skema fully funded diterapkan pada sistem pensiun PNS di Indonesia, maka ketentuan bagi PNS yang telah pensiun untuk memilih menarik dana sekaligus atau bulanan diakomodasi dalam peraturan. Namun terdapat 5 responden $(16,7 \%)$ sangat tidak setuju dan sebanyak 5 responden $(16,7 \%)$ tidak setuju dengan pernyataan ini, sedangkan terdapat 2 responden $(6,7 \%)$ bersikap netral bahwa ketentuan bagi PNS yang telah pensiun untuk memilih menarik dana sekaligus atau bulanan diakomodasi dalam peraturan sehubungan dengan penerapan skema fully funded pada sistem pensiun PNS di Indonesia.

Berdasarkan hasil perhitungan nilai rata-rata pembobotan kuesioner, pernyataan P13 bernilai sebesar 196 poin, dengan nilai rata-rata sebesar 3,20 . Poin 3,20 ini berada pada rentang pendapat netral (N) dan setuju (S). Hal ini menunjukkan bahwa responden cenderung netral dengan pernyataan apabila pemerintah akan menerapkan skema fully funded pada sistem pensiun PNS di Indonesia, maka ketentuan bagi PNS yang telah pensiun untuk memilih menarik dana sekaligus atau bulanan diakomodasi dalam peraturan.

Berdasarkan kuesioner yang telah diterima dan diolah, keempat instansi sebagai narasumber responden memiliki pendapat yang cukup beragam bahwa peraturan mengenai jaminan minimum pensiun perlu diterapkan dan diakomodasi dalam peraturan.

Dalam pelaksanaan sistem pensiun dengan skema fully funded, masing-masing iuran peserta ditempatkan dalam rekening pribadi dan tidak tercampur dengan peserta yang lainnya. Dengan demikian, besaran dana yang tersedia untuk 
mendanai pensiun setiap peserta telah diketahui. Berdasarkan hal tersebut, maka peserta kemudian dapat memilih untuk mengambil manfaat pensiun tersebut sekaligus atau secara langsung atau bahkan memilih untuk menginvestasikan kembali dana pensiun yang diperoleh kepada lembaga dana pensiun yang lain. Apabila hal ini akan diterapkan dan diakomodasi ke dalam peraturan yang mengatur sistem pensiun yang digunakan, berdasarkan kuesioner yang telah diterima dan diolah, keempat instansi sebagai narasumber responden memiliki pendapat yang cukup beragam bahwa ketentuan bagi pegawai negeri yang telah pensiun dapat menarik dana sekaligus atau bulanan diakomodasi dalam peraturan.

\subsection{Risiko Penerapan Skema Fully Funded}

Seperti penjelasan sebelumnya, skema fully funded sangat bergantung pada iuran peserta dan iklim investasi suatu negara agar iuran yang terkumpul dapat dikembangkan secara maksimal. Tetapi, ketika iklim investasi tidak stabil, maka terjadi kekhawatiran terhadap pengembangan dana pensiun. Ketika iklim investasi buruk, akan menghasilkan pengembalian yang tidak maksimal atau bahkan dapat menyebabkan kerugian. Hal ini harus diwaspadai dan menjadi pertimbangan ketika pemerintah akan menerapkan mekanisme fully funded.

Hasil pengolahan data dari kuesioner yang dikumpulkan mengenai Risiko Penerapan Skema Fully Funded dapat dilihat pada Tabel 4.5. Berdasarkan hasil distribusi frekuensi subbagian risiko dalam penerapan skema fully funded, dapat diketahui bahwa sebanyak $12,2 \%$ responden sangat setuju dan $37,8 \%$ responden setuju bahwa terdapat beberapa risiko yang akan dihadapi baik oleh pemerintah maupun PNS apabila menerapkan skema fully funded pada sistem pensiunnya. Namun terdapat 5,6\% responden yang sangat tidak setuju dan $18,9 \%$ tidak setuju dengan pernyataan tersebut, sedangkan sebanyak $25,6 \%$ responden bersikap netral terhadap risiko yang akan dihadapi baik oleh pemerintah maupun PNS apabila menerapkan skema fully funded pada sistem pensiunnya. Jika dilihat dari jumlah pembobotan nilai kuesioner pada bagian ini, secara umum, jumlah nilai bagian ini sebesar 299 dengan nilai rata-rata sebesar 3,32. Jumlah ini berada pada rentang pendapat netral (N) dan setuju (S).

Pengolahan jawaban responden terhadap pernyataan P14 kuesioner menunjukkan bahwa sebanyak 5 responden $(16,7 \%)$ berpendapat bahwa mereka sangat setuju dan sebanyak 16 responden $(53,3 \%)$ berpendapat bahwa mereka setuju apabila skema fully funded diterapkan pada sistem pensiun PNS di Indonesia, maka terdapat risiko tingkat pengembalian dari pengembangan dana pensiun tidak sesuai dengan apa yang diharapkan. Namun, terdapat 1 responden $(3,3 \%)$ yang berpendapat tidak setuju mengenai pernyataan ini, sedangkan terdapat 8 responden $(26,7 \%)$ yang bersikap netral terdapat risiko tingkat pengembalian dari pengembangan dana pensiun tidak sesuai dengan apa yang diharapkan sehubungan dengan penerapan skema fully funded pada sistem pensiun PNS di Indonesia.

Berdasarkan hasil perhitungan nilai rata-rata pembobotan kuesioner, pernyataan P14 bernilai sebesar 115 poin, dengan nilai rata-rata sebesar 3,83 . Poin 3,83 ini berada pada rentang pendapat netral (N) dan setuju (S). Hal ini menunjukkan bahwa responden bersikap netral tetapi mendekati setuju dengan pernyataan apabila pemerintah akan menerapkan skema fully funded pada sistem pensiun PNS di Indonesia, maka terdapat risiko tingkat pengembalian dari pengembangan dana pensiun tidak sesuai dengan apa yang diharapkan atau tidak maksimal.

Pengolahan jawaban responden terhadap pernyataan P15 kuesioner menunjukkan bahwa sebanyak 5 responden $(16,7 \%)$ berpendapat bahwa mereka sangat setuju dan sebanyak 11 responden $(36,7 \%)$ berpendapat bahwa mereka setuju apabila skema fully funded diterapkan pada sistem pensiun PNS di Indonesia, terdapat kemungkinan risiko investasi dana pensiun yang akan ditanggung oleh PNS. Namun terdapat 9 responden $(30 \%)$ yang berpendapat tidak setuju terhadap kemungkinan ini, sedangkan terdapat 5 responden $(16,7 \%)$ yang bersikap netral terhadap adanya kemungkinan risiko investasi dana pensiun ditanggung oleh PNS sehubungan dengan penerapan skema fully funded pada sistem pensiun PNS di Indonesia.

Berdasarkan hasil perhitungan nilai rata-rata pembobotan kuesioner, pernyataan P15 bernilai sebesar 102 poin, dengan nilai rata-rata sebesar 3,40 . Poin 3,40 ini berada pada rentang pendapat netral (N) dan setuju (S). Hal ini menunjukkan bahwa responden bersikap netral tetapi mendekati setuju dengan pernyataan apabila pemerintah akan menerapkan skema fully funded pada sistem pensiun PNS di Indonesia, maka terdapat kemungkinan risiko investasi dana pensiun yang akan ditanggung oleh PNS.

Pengolahan jawaban responden terhadap pernyataan P16 kuesioner menunjukkan bahwa sebanyak 1 responden $(3,3 \%)$ berpendapat bahwa mereka sangat setuju dan sebanyak 7 responden $(23,3 \%)$ berpendapat bahwa mereka setuju apabila skema fully funded diterapkan pada sistem pensiun PNS di Indonesia, terdapat potensi biaya yang ditanggung pemerintah terkait jumlah minimum pensiun yang diterima PNS. Namun terdapat 5 responden $(16,7 \%)$ yang berpendapat sangat tidak setuju dan 7 responden (23,3\%) tidak setuju 
terhadap kemungkinan ini, sedangkan terdapat 23 responden $(33,3 \%)$ yang bersikap netral terhadap adanya kemungkinan potensi biaya yang ditanggung pemerintah terkait jumlah minimum pensiun yang diterima PNS sehubungan dengan penerapan skema fully funded pada sistem pensiun PNS di Indonesia.

Berdasarkan hasil perhitungan nilai rata-rata pembobotan kuesioner, pernyataan P16 bernilai sebesar 102 poin, dengan nilai rata-rata sebesar 3,40 . Poin 3,40 ini berada pada rentang pendapat netral $(\mathrm{N})$ dan setuju (S). Hal ini menunjukkan bahwa responden bersikap netral tetapi mendekati setuju dengan pernyataan apabila pemerintah akan menerapkan skema fully funded pada sistem pensiun PNS di Indonesia, maka terdapat potensi biaya yang ditanggung pemerintah terkait jumlah minimum pensiun yang diterima PNS.

Berdasarkan kuesioner yang telah diterima dan diolah, keempat instansi sebagai narasumber responden setuju bahwa terdapat risiko tingkat pengembalian dari pengembangan dana pensiun tidak sesuai dengan apa yang diharapkan.

Risiko berikutnya yang akan dihadapi pemerintah ketika menerapkan skema fully funded adalah terjadi pemindahan penanggung risiko. Ketika skema pay as you go dilaksanakan, pemerintah menanggung risiko pembiayaan manfaat pensiun yang membebani APBN. Ketika skema fully funded diterapkan, terjadi perpindahan risiko dari pemerintah ke pegawai negeri sebagai peserta. Hal ini tentunya harus menjadi perhatian oleh pemerintah ketika akan menerapkan skema fully funded dalam sistem pensiun pegawai negeri. Terhadap hal ini, hasil kuesioner menunjukkan bahwa responden lebih bersikap netral apabila terjadi perpindahan risiko dari pemerintah ke pegawai negeri.

\subsection{Dampak Penerapan Skema Fully Funded pada Anggaran Pendapatan dan Belanja Negara}

Untuk melihat pengaruh dari penerapan skema fully funded pada APBN, penulis melakukan simulasi sederhana. Dari perhitungan tersebut terlihat bahwa akan terjadi penambahan beban pada APBN untuk membiayai pensiun dikarenakan selain pemerintah harus membayar pensiun pegawai yang masih menggunakan skema pay as you go, pemerintah juga harus membayar iuran pensiun pegawai sebagai konsekuensi dari diterapkannya skema fully funded pada pegawai negeri yang masuk pada tahun 2017. Dari hasil perhitungan terlihat bahwa penerapan skema fully funded pada sistem pensiun pegawai negeri, pada awalnya akan membebani APBN karena adanya penambahan kewajiban pemerintah dalam membayar kontribusi. Namun, manfaat skema fully funded ini dapat dilihat pada tahun 2047 dimana pegawai negeri yang masuk 2017 sudah memasuki usia pensiun.

Asumsikan pegawai negeri yang masuk pada 2017 pensiun pada 2046 dimana gaji pokok terakhir sebesar Rp5.068.000,- (menggunakan dasar perhitungan PP 30 Tahun 2015). Dengan demikian, dasar pensiun yang diterima adalah sebesar 75\% dari gaji pokok terakhir yaitu Rp3.801.000. Dengan jumlah pegawai yang pensiun pada saat itu sebanyak 100.000 pegawai, maka jumlah beban pensiun yang akan ditanggung pemerintah jika masih menggunakan skema pay as you go, perbulan sebesar Rp380.100.000.000 atau dalam setahun sebesar Rp4.561.200.000.000. Jumlah tersebut tentu akan menambah beban APBN. Namun apabila pemerintah menggunakan skema fully funded, maka pada tahun 2046 tidak akan terjadi penambahan beban APBN sebesar Rp4.561.200.000.000 tersebut karena beban itu akan ditanggung oleh dana pensiun yang telah dikumpulkan dan dikembangkan sebelumnya.

Dengan demikian dapat dikatakan bahwa perubahan skema dari pay as you go menjadi fully funded dalam waktu dekat belum dapat terlihat manfaatnya secara langsung. Oleh karena itu, jika pemerintah akan menerapkan skema fully funded ini, haruslah memiliki komitmen yang kuat agar selama proses transisi dapat berjalan dengan baik dan tidak mengalami perubahan-perubahan kebijakan yang membuat skema fully funded gagal dilaksanakan.

\subsection{Kesiapan Pemerintah dalam Menerapkan Skema Fully Funded}

Untuk menerapkan skema fully funded, hal yang paling utama yang dibutuhkan adalah adanya peraturan yang melandasi pelaksanaan sistem tersebut. Hingga saat ini, Kementerian PAN-RB telah berhasil menyusun Rancangan Peraturan Pemerintah (RPP) tentang Jaminan Pensiun dan Hari Tua. Namun dari hasil penelitian yang dilakukan, rancangan tersebut masih terdapat kekurangan.

Dalam rancangan yang disusun Kementerian PAN-RB, masih terdapat kekurangan-kekurangan yang harus diperbaiki agar RPP tersebut dapat ditetapkan menjadi Peraturan Pemerintah. Kekurangan yang paling utama adalah dalam RPP tersebut belum mengadopsi peraturan-peraturan yang menjadi landasan hukum pelaksanaan pensiun dengan sistem lama. Jika landasan hukum yang lama dihilangkan dan tidak diadopsi dalam peraturan yang baru, maka pensiun yang berjalan sebelum peraturan yang baru ditetapkan tidak memiliki landasan hukum. RPP yang disusun juga masih mengatur mengenai jaminan kecelakaan kerja dan jaminan kematian yang sebenarnya saat ini telah diatur dalam suatu Peraturan Pemerintah. 
Pengelola dana pensiun masih menjadi perdebatan apakah tetap akan dilakukan oleh PT. TASPEN atau dikembalikan kepada Kementerian Keuangan. Perubahan pengelola dana pensiun ini masih harus didiskusikan lebih lanjut mengingat yang akan dikelola oleh lembaga pensiun tersebut merupakan iuran yang berasal dari peserta dan pemerintah.

Besaran iuran yang harus disetorkan kepada pengelola dana pensiun pun masih belum dapat diputuskan mengingat keputusan tersebut sangat bergantung pada besaran penghasilan yang diperoleh PNS. Hingga saat ini Kementerian PANRB masih belum menyelesaikan peraturan pemerintah mengenai gaji pegawai negeri. Dengan demikian, besaran iuran yang merupakan unsur penting dalam pelaksanaan sistem pensiun belum juga dapat diputuskan.

\section{KESIMPULAN DAN SARAN}

Berdasarkan penelitian dan pembahasan yang telah diuraikan dalam bab-bab sebelumnya, maka sehubungan dengan adanya rencana perubahan sistem pensiun PNS di Indonesia dari yang semula menerapkan skema pay as you go dimana pemerintah membayarkan manfaat pensiun kepada pegawai negeri, menjadi menggunakan skema fully funded dimana pemerintah hanya membayarkan kontribusi sedangkan manfaat pensiun akan ditanggung oleh lembaga dana pensiun, dapat ditarik kesimpulan sebagai berikut:

\section{Indonesia dapat menerapkan fully funded pada sistem pensiun Pegawai Negeri Sipil.}

Kesimpulan ini dapat ditarik berdasarkan hasil penelitian pada bab-bab sebelumnya, yaitu: pihak terkait dengan kebijakan pensiun di Indonesia, Kementerian PAN-RB, Direktorat Anggaran, dan Direktorat Jenderal Perbendaharaan Kementerian Keuangan selaku perumus kebijakan, dan PT TASPEN sebagai lembaga yang saat ini menjadi penyelenggaran sistem pensiun di Indonesia memiliki kesamaan pendapat dan kesepahaman mengenai hal-hal yang perlu diterapkan atau dilakukan ketika skema fully funded akan dilaksanakan pada sistem pensiun pegawai negeri, yaitu:

a. Jumlah premi iuran untuk pensiun saat ini perlu ditingkatkan. Seperti yang telah dibahas dan dilakukan simulasi pada bab sebelumnya, terlihat bahwa jika iuran pensiun yang dipungut dari peserta sebesar $4,75 \%$ dari gaji pokok tetap dipertahankan, maka hasil pengembangan dana pensiun tidak akan cukup untuk memenuhi kebutuhan pegawai yang telah memasuki usia pensiun.

b. Pemerintah dan PNS melakukan pembayaran iuran dengan mekanisme sharing method.
Seperti yang dijelaskan pada poin 1, iuran yang saat ini dipungut untuk kemudian disetorkan kepada pengelola dana pensiun hanya berasal dari pegawai negeri saja. Tentunya dengan diberlakukannya skema fully funded dimana persentase iuran akan dinaikkan, maka harus ada pembagian kewajiban antara pemerintah selaku pemberi kerja dengan pegawai negeri selaku pekerja.

c. Setiap PNS perlu dibuatkan rekening dana pensiun masing-masing peserta oleh pengelola dana pensiun dengan tujuan agar peserta dapat mengetahui perkembangan saldo akun pensiunnya dan pada dasarnya akun tersebut dapat dibuat bersifat portable sehingga ketika pegawai tersebut memasuki masa pensiun dapat memutuskan apakah akan mengambil dana tesebut atau berniat untuk menginvestasikan kembali.

d. Untuk meminimalkan risiko, investasi dana pensiun dapat diinvestasikan dalam bentuk portofolio Surat Berharga. Karena pada skema fully funded ini risiko investasi akan ditanggung sepenuhnya oleh peserta, maka sudah menjadi kewajiban pengelola dana untuk memastikan investasinya aman dan tidak merugikan peserta.

e. Investasi Dana Pensiun harus menghasilkan tingkat pengembalian yang optimal. Karena pembayaran manfaat pensiun sangat bergantung pada seberapa besar dana dapat dikembangkan, maka perlu menjadi perhatian bagi penyelenggara untuk memberikan usaha yang optimal agar dana pensiun dapat berkembang dengan baik demi kepentingan pegawai negeri yang memasuki usia pensiun.

f. Adanya risiko tingkat pengembalian dari pengembangan dana pensiun tidak sesuai dengan apa yang diharapkan. Hal ini harus menjadi perhatian pemerintah, dengan penerapan skema fully funded pemerintah tetap memiliki tanggung jawab untuk memperhatikan risiko yang diemban oleh pegawai negeri.

\section{Hingga saat ini, Indonesia dapat dikatakan belum siap untuk menerapkan skema fully funded sistem pensiun Pegawai Negeri Sipil.}

Kesimpulan ini dapat ditarik berdasarkan hasil penelitian pada bab-bab sebelumnya yaitu masih banyak hal-hal yang perlu dilakukan pemerintah sehubungan dengan penerapan skema fully funded ini seperti:

a. Peraturan yang menjadi landasan hukum pelaksanaan skema fully funded hingga saat ini masih belum ada. Saat ini landasan hukum tersebut sedang disusun oleh Kementerian PAN-RB. Namun, rancangan peraturan 
pemerintah tersebut masih banyak kekurangan-kekurangan yang harus diperbaiki.

b. Pemerintah belum menetapkan pengelola dana pensiun ketika menerapkan skema fully funded. Hingga saat ini masih terjadi perdebatan apakah PT. TASPEN akan menjadi pengelola dana pensiun PNS ataukah pengelolaan tersebut akan diambil alih oleh pemerintah melalui Kementerian Keuangan.

c. Keputusan mengenai besaran iuran yang harus disetorkan kepada dana pensiun untuk dikembangkan masih belum diputuskan. Pemerintah masih terus mengkaji untuk mencari besaran iuran yang sesuai diterapkan pada skema fully funded ini. Berdasarkan usulan terakhir, diusulkan iuran sebesar 11\% dari gaji pokok pegawai.

Pemerintah juga belum menetapkan sumber dana yang akan digunakan untuk membayar iuran kepada dana pensiun yang menjadi kewajiban pemerintah jika skema fully funded diterapkan. Usulan menggunakan PPh 21 yang dipungut dari gaji pokok pegawai pun masih belum disepakati karena PPh 21 tersebut tidak bersifat riil dalam pendanaan, berbeda dengan PPh 21 tunjangan kinerja yang bersifat riil.

\section{IMPLIKASI DAN KETERBATASAN}

Penulis menyadari dalam penulisan ini masih belum dapat dikatakan sempurna untuk menjelaskan masalah yang diangkat dalam penelitian ini. Keterbatasan penelitian ini antara lain:

1. Penelitian ini hanya melibatkan pihak-pihak yang terkait langsung dengan perumusan dan pelaksanaan kebijakan pensiun PNS di Indonesia sehingga jumlah responden terbatas.

2. Dikarenakan belum adanya penelitian yang membahas masalah sistem pensiun ini dengan menggunakan kuesioner, maka kuesioner dalam penelitian dibuat dengan cara mengumpulkan informasi dari hasil studi pustaka dan benchmarking dengan negara lain. Oleh karena itu, kemungkinan terdapat kekurangan dalam penyusunan kuesioner ini dan belum sempurna untuk menggambarkan kondisi yang ada pada sistem pensiun di Indonesia.

\section{PENGHARGAAN (ACKNOWLEDGEMENT)}

Penulis menyadari bahwa dalam proses penyusunan karya tulis ilmiah ini tidak lepas dari bantuan, dukungan dan bimbingan dari berbagai pihak. Oleh karena itu, pada kesempatan ini penulis ingin mengucapkan terima kasih sebesarbesarnya.

\section{DAFTAR PUSTAKA (REFERENCES)}

Acuna, R, Rodrigo dan Augusto Iglesias P. (2001). "Chile's Pension Reform after 20 Years", Social Protection Discussion Paper, Series No. 0129, the World Bank.

Asher, Mukul G. (2000). "Reforming Civil Service Pensions in Selected Asian Countries". Social Security Workshop, the World Bank.

Attah, Edward dan Botchwey. (2014). "Best Practice Systems in Developing Nations". International Journal of Humanities and Social Science, Vol. 4 No. 9 (01), hlm. 236248.

Buchholz, G.J., Coutasse, A., Silva, P., \& Hilsenrath, P. (2008). "The Chilean Pension System at 25 Years: The Evolution of a Revolution". Journal of Economic Issues, Vol. 42(3), hlm. 633-647.

Feldstein, Martin. (1997). "Transition To A Fully Funded Pension System: Five Economic Issues", NBER Working Paper, No. 6149.

Guillen, Joge B. dan Ruben Mosqueda. (2013). "Pay As You Go System versus Fully Funded Pension in Peru". Ecos do Economia, No. 6 , hlm. 5-19.

Hanafie, Haniah. (2014). "Alternatif Sistem Pembayaran Pensiun Pegawai Negeri Sipil", Jurnal Kebijakan dan Manajemen PNS, Vol. 8, No. 2, hlm. 43-50.

Hayman, David N, (2011). Public Finance a Contemporary Aplication of Theory to Policy. Mason: South-Western Cengage Learning.

Ho, Lok Sang. (1997). "A Universal Fully Funded Pension Scheme", Social Science Journal, hlm. 13-20.

Horne, James C. Van. dan John M. Wachowicz, Jr. Fundamentals of Financial Management, 13th Edition. New Jersey: Prentice Hall.

Natalya Shnitser. (2015). "Funding Discipline for U.S. Public Pension Plans: An Empirical Analysis of Institutional Design", Iowa Law Review, Vol. 100, No.2, hlm. 663-713.

Nugraha, Agus. (2014). "Kebijakan Pensiun Pegawai Negeri Sipil (PNS) Dalam Perspektif Ekonomi Politik", Jurnal Kebijakan dan Manajemen PNS, Vol. 8, No. 2, hlm. 15-25.

Peraturan Pemerintah No. 15 Tahun 1963 tentang Pendirian Perusahaan Negara Dana Tabungan dan Asuransi Pegawai Negeri. 
Peraturan Pemerintah No. 25 Tahun 1981 tentang Asuransi Sosial Pegawai Negeri.

Ponds, E., C. Severinson and J. Yermo. (2011), "Fundingin Public Sector Pension Plans: International Evidence", OECD Working Papers on Finance, Insurance and Private Pensions, No. 8, OECD Publishing.

Purwoko, Bambang. (2014). "Reformasi Program Pensiun Pegawai Negeri Sipil: Studi Kasus Reformasi Sistem Pensiun Pegawai Sektor Publik di Berbagai Negara", Jurnal Kebijakan dan Manajemen PNS, Vol. 8, No. 2, hlm. 2741.

Rakhmawanto, Ajib. (2014). "Program Pensiun Pegawai Negeri Sipil: Analisis Perspektif Perbaikan Sistem Pensiun PNS dari Pay As You Go ke Fully Funded", Jurnal Kebijakan dan Manajemen PNS, Vol. 8, No. 2, hlm. 1-13.

Simanungkalit, Janry Haposan U.P. (2014). "Redesign Sistem Pensiun Pegawai Negeri Sipil di Indonesia", Jurnal Kebijakan dan Manajemen PNS, Vol. 8, No. 2, hlm. 51-68.

Sugiyono. (2012). Metode Penelitian Kuantitatif Kualitatif dan R\&D. Jakarta: Alfabeta.

Suripto. (2014). "Sistem Pensiun PNS: Mewujudkan Sistem Pendanaan Pensiun Fully Funded". Jurnal Kebijakan dan Manajemen PNS, Vol. 8, No. 2, hlm. 83-92.

Stice dan Stice. (2008). Intermediate Accounting, Mason: South-Western Cengage Learning.

Sulistyo, Agustinus. (2012). "Reformasi Sistem Pensiun PNS", Info Kajian LAN.

Undang-Undang No. 11 Tahun 1969 tentang Pensiun Pegawai Negeri dan Janda/ Duda Pegawai.

Undang-Undang No. 11 Tahun 1992 tentang Dana Pensiun.

Undang-Undang No. 17 Tahun 2003 tentang Keuangan Negara. 


\section{ILUSTRASI TABEL}

Tabel 4.1. Distribusi Frekuensi Subbagian Pengelola Dana Pensiun

\begin{tabular}{|c|c|c|c|c|c|c|c|}
\hline \multirow{3}{*}{ No } & \multirow{3}{*}{ Pernyataan } & STS & TS & $\mathrm{N}$ & $S$ & SS & Total \\
\hline & & Jumlah & Jumlah & Jumlah & Jumlah & Jumlah & Jumlah \\
\hline & & $\%$ & $\%$ & $\%$ & $\%$ & $\%$ & $\%$ \\
\hline \multirow{3}{*}{1} & \multirow{3}{*}{ P1 } & 0 & 0 & 2 & 17 & 11 & 30 \\
\hline & & $0.0 \%$ & $0.0 \%$ & $6.7 \%$ & $56.7 \%$ & $36.7 \%$ & $100.0 \%$ \\
\hline & & \multicolumn{2}{|c|}{ Jumlah Poin } & 129 & \multicolumn{2}{|c|}{ Rata-Rata } & 4.30 \\
\hline \multirow{3}{*}{2} & \multirow{3}{*}{ P2 } & 0 & 0 & 2 & 22 & 6 & 30 \\
\hline & & $0.0 \%$ & $0.0 \%$ & $6.7 \%$ & $73.3 \%$ & $20.0 \%$ & $100.0 \%$ \\
\hline & & \multicolumn{2}{|c|}{ Jumlah Poin } & 124 & \multicolumn{2}{|c|}{ Rata-Rata } & 4.13 \\
\hline \multirow{6}{*}{3} & \multirow{3}{*}{ P3 } & 7 & 2 & 2 & 14 & 5 & 30 \\
\hline & & $23.3 \%$ & $6.7 \%$ & $6.7 \%$ & $46.7 \%$ & $16.7 \%$ & $100.0 \%$ \\
\hline & & \multicolumn{2}{|c|}{ Jumlah Poin } & 98 & \multicolumn{2}{|c|}{ Rata-Rata } & 3.27 \\
\hline & Jumlah & 7 & 2 & 6 & 53 & 22 & 90 \\
\hline & Persentase & $8 \%$ & $2 \%$ & $7 \%$ & $59 \%$ & $24 \%$ & $100 \%$ \\
\hline & & \multicolumn{2}{|r|}{ Poin } & 351 & \multicolumn{2}{|c|}{ Rata-Rata } & 3.9 \\
\hline
\end{tabular}

Sumber: Hasil pengolahan data kuesioner Subbagian Iuran/Kontribusi Peserta dengan menggunakan Microsoft Excell.

Tabel 4.2. Distribusi Frekuensi Subbagian Iuran/Kontribusi Peserta

\begin{tabular}{|c|c|c|c|c|c|c|c|}
\hline \multirow{3}{*}{ No } & \multirow{3}{*}{ Pernyataan } & STS & TS & $\mathrm{N}$ & $S$ & SS & Total \\
\hline & & Jumlah & Jumlah & Jumlah & Jumlah & Jumlah & Jumlah \\
\hline & & $\%$ & $\%$ & $\%$ & $\%$ & $\%$ & $\%$ \\
\hline \multirow{3}{*}{1} & \multirow{3}{*}{ P4 } & 0 & 0 & 6 & 15 & 9 & 30 \\
\hline & & $0.0 \%$ & $0.0 \%$ & $20.0 \%$ & $50.0 \%$ & $30.0 \%$ & $100.0 \%$ \\
\hline & & \multicolumn{2}{|c|}{ Jumlah Poin } & 123 & \multicolumn{2}{|c|}{ Rata-Rata } & 4.10 \\
\hline \multirow{3}{*}{2} & \multirow{3}{*}{ P5 } & 0 & 0 & 3 & 16 & 11 & 30 \\
\hline & & $0.0 \%$ & $0.0 \%$ & $10.0 \%$ & $53.3 \%$ & $36.7 \%$ & $100.0 \%$ \\
\hline & & \multicolumn{2}{|c|}{ Jumlah Poin } & 128 & \multicolumn{2}{|c|}{ Rata-Rata } & 4.27 \\
\hline \multirow{6}{*}{3} & \multirow{3}{*}{ P6 } & 0 & 0 & 10 & 7 & 13 & 30 \\
\hline & & $0.0 \%$ & $0.0 \%$ & $33.3 \%$ & $23.3 \%$ & $43.3 \%$ & $100.0 \%$ \\
\hline & & \multicolumn{2}{|c|}{ Jumlah Poin } & 123 & \multicolumn{2}{|c|}{ Rata-Rata } & 4.10 \\
\hline & Jumlah & 0 & 0 & 19 & 38 & 33 & 90 \\
\hline & Persentase & $0 \%$ & $0 \%$ & $21 \%$ & $42 \%$ & $37 \%$ & $100 \%$ \\
\hline & & \multicolumn{2}{|c|}{ Jumlah Poin } & 374 & \multicolumn{2}{|c|}{ Rata-Rata } & 4.155556 \\
\hline
\end{tabular}

Sumber: Hasil pengolahan data kuesioner subbagian Iuran/ Kontribusi Peserta dengan menggunakan Microsoft Excell. 
Tabel 4.3. Distribusi Frekuensi Subbagian Investasi Dana Pensiun

\begin{tabular}{|c|c|c|c|c|c|c|c|}
\hline \multirow{3}{*}{ No } & \multirow{3}{*}{ Pernyataan } & STS & TS & $\mathrm{N}$ & $S$ & SS & Total \\
\hline & & Jumlah & Jumlah & Jumlah & Jumlah & Jumlah & Jumlah \\
\hline & & $\%$ & $\%$ & $\%$ & $\%$ & $\%$ & $\%$ \\
\hline \multirow{3}{*}{1} & \multirow{3}{*}{ P7 } & 0 & 0 & 7 & 15 & 8 & 30 \\
\hline & & $0.0 \%$ & $0.0 \%$ & $23.3 \%$ & $50.0 \%$ & $26.7 \%$ & $100.0 \%$ \\
\hline & & \multicolumn{2}{|c|}{ Jumlah poin } & 121 & \multicolumn{2}{|c|}{ Rata-Rata } & 4.03 \\
\hline \multirow{3}{*}{2} & \multirow{3}{*}{ P8 } & 0 & 0 & 0 & 20 & 10 & 30 \\
\hline & & $0.0 \%$ & $0.0 \%$ & $0.0 \%$ & $66.7 \%$ & $33.3 \%$ & $100.0 \%$ \\
\hline & & \multicolumn{2}{|c|}{ Jumlah poin } & 130 & \multicolumn{2}{|c|}{ Rata-Rata } & 4.33 \\
\hline \multirow{6}{*}{3} & \multirow{3}{*}{ P9 } & 7 & 2 & 10 & 7 & 4 & 30 \\
\hline & & $23.3 \%$ & $6.7 \%$ & $33.3 \%$ & $23.3 \%$ & $13.3 \%$ & $100.0 \%$ \\
\hline & & \multicolumn{2}{|c|}{ Jumlah poin } & 89 & \multicolumn{2}{|c|}{ Rata-Rata } & 2.97 \\
\hline & Jumlah & 7 & 2 & 17 & 42 & 22 & 90 \\
\hline & Persentase & $7.8 \%$ & $2.2 \%$ & $18.9 \%$ & $46.7 \%$ & $24.4 \%$ & $100 \%$ \\
\hline & & \multicolumn{2}{|c|}{ Jumlah Poin } & 340 & \multicolumn{2}{|c|}{ Rata-Rata } & 3.777778 \\
\hline
\end{tabular}

Sumber: Hasil pengolahan data kuesioner Subbagian Investasi Dana Pensiun dengan menggunakan Microsoft Excell.

Tabel 4.4. Distribusi Frekuensi Subbagian Peraturan

\begin{tabular}{|c|c|c|c|c|c|c|c|}
\hline \multirow{3}{*}{ No } & \multirow{3}{*}{ Pernyataan } & STS & TS & $\mathrm{N}$ & $\mathrm{S}$ & SS & Total \\
\hline & & Jumlah & Jumlah & Jumlah & Jumlah & Jumlah & Jumlah \\
\hline & & $\%$ & $\%$ & $\%$ & $\%$ & $\%$ & $\%$ \\
\hline \multirow{3}{*}{1} & \multirow{3}{*}{ P10 } & 0 & 0 & 1 & 20 & 9 & 30 \\
\hline & & $0.0 \%$ & $0.0 \%$ & $3.3 \%$ & $66.7 \%$ & $30.0 \%$ & $100.0 \%$ \\
\hline & & \multicolumn{2}{|c|}{ Jumlah Poin } & 128 & \multicolumn{2}{|c|}{ Rata-Rata } & 4.27 \\
\hline \multirow{3}{*}{2} & \multirow{3}{*}{ P11 } & 0 & 0 & 0 & 17 & 13 & 30 \\
\hline & & $0.0 \%$ & $0.0 \%$ & $0.0 \%$ & $56.7 \%$ & $43.3 \%$ & $100.0 \%$ \\
\hline & & \multicolumn{2}{|c|}{ Jumlah Poin } & 133 & \multicolumn{2}{|c|}{ Rata-Rata } & 4.43 \\
\hline \multirow{3}{*}{3} & \multirow{3}{*}{ P12 } & 4 & 5 & 1 & 17 & 3 & 30 \\
\hline & & $13.3 \%$ & $16.7 \%$ & $3.3 \%$ & $56.7 \%$ & $10.0 \%$ & $100.0 \%$ \\
\hline & & \multicolumn{2}{|c|}{ Jumlah Poin } & 100 & \multicolumn{2}{|c|}{ Rata-Rata } & 3.33 \\
\hline \multirow{6}{*}{4} & \multirow{3}{*}{ P13 } & 5 & 5 & 2 & 15 & 3 & 30 \\
\hline & & $16.7 \%$ & $16.7 \%$ & $6.7 \%$ & $50.0 \%$ & $10.0 \%$ & $100.0 \%$ \\
\hline & & \multicolumn{2}{|c|}{ Jumlah Poin } & 96 & \multicolumn{2}{|c|}{ Rata-Rata } & 3.20 \\
\hline & Jumlah & 9 & 10 & 4 & 69 & 28 & 120 \\
\hline & Persentase & $7.5 \%$ & $8.3 \%$ & $3.3 \%$ & $57.5 \%$ & $23.3 \%$ & $100 \%$ \\
\hline & & \multicolumn{2}{|c|}{ Jumlah Poin } & 457 & \multicolumn{2}{|c|}{ Rata-Rata } & 3.808333 \\
\hline
\end{tabular}

Sumber: Hasil pengolahan data kuesioner Subbagian Peraturan dengan menggunakan Microsoft Excell. 
Tabel 4.5. Distribusi Frekuensi Subbagian Risiko

\begin{tabular}{|c|c|c|c|c|c|c|c|}
\hline \multirow{3}{*}{ No } & \multirow{3}{*}{ Pernyataan } & STS & TS & $\mathrm{N}$ & $S$ & SS & Total \\
\hline & & Jumlah & Jumlah & Jumlah & Jumlah & Jumlah & Jumlah \\
\hline & & $\%$ & $\%$ & $\%$ & $\%$ & $\%$ & $\%$ \\
\hline \multirow{3}{*}{1} & \multirow{3}{*}{ P14 } & 0 & 1 & 8 & 16 & 5 & 30 \\
\hline & & $0.0 \%$ & $3.3 \%$ & $26.7 \%$ & $53.3 \%$ & $16.7 \%$ & $100.0 \%$ \\
\hline & & \multicolumn{2}{|c|}{ Jumlah Poin } & 115 & \multicolumn{2}{|c|}{ Rata-Rata } & 3.83 \\
\hline \multirow{3}{*}{2} & \multirow{3}{*}{ P15 } & 0 & 9 & 5 & 11 & 5 & 30 \\
\hline & & $0.0 \%$ & $30.0 \%$ & $16.7 \%$ & $36.7 \%$ & $16.7 \%$ & $100.0 \%$ \\
\hline & & \multicolumn{2}{|c|}{ Jumlah Poin } & 102 & \multicolumn{2}{|c|}{ Rata-Rata } & 3.40 \\
\hline \multirow{6}{*}{2} & \multirow{3}{*}{ P16 } & 5 & 7 & 10 & 7 & 1 & 30 \\
\hline & & $16.7 \%$ & $23.3 \%$ & $33.3 \%$ & $23.3 \%$ & $3.3 \%$ & $100.0 \%$ \\
\hline & & \multicolumn{2}{|c|}{ Jumlah Poin } & 102 & \multicolumn{2}{|c|}{ Rata-Rata } & 3.40 \\
\hline & Jumlah & 5 & 17 & 23 & 34 & 11 & 90 \\
\hline & Persentase & $5.6 \%$ & $18.9 \%$ & $25.6 \%$ & $37.8 \%$ & $12.2 \%$ & $100 \%$ \\
\hline & & \multicolumn{2}{|c|}{ Jumlah Poin } & 299 & \multicolumn{2}{|c|}{ Rata-Rata } & 3.322222 \\
\hline
\end{tabular}

Sumber: Hasil pengolahan data kuesioner Subbagian Investasi Dana Pensiun dengan menggunakan Microsoft Excell. 